\title{
Introduction of the American Pediatric Society's 2008 John Howland Award Recipient, Richard B. Johnston Jr, M.D.
}

\author{
LAURENCE A. BOXER \\ Department of Pediatrics, University of Michigan, Women's Hospital, Ann Arbor, Michigan 48109
}

$\mathrm{P}$ resident Hay, members of the American Pediatrics Society, and guests, it gives me particular pleasure to present to you the recipient of this year's John Howland Award, Dr. Richard B. Johnston Jr.

Dick's father, Richard, was sales manager for Fleischmann Distilling Corporation (Fig. 1B). Dick's father attended Lehigh University. He was an accomplished collegiate athlete. He lettered in football, basketball, and baseball each of his $4 \mathrm{y}$ of college. His father transmitted to his son, a competitive spirit and the need to work hard, but play fair. His mother, Jane Dillon (Fig. 1A), graduated from the University of Illinois with a major in English. Jane Dillon had a profound influence on the intellectual pursuits of her four sons. She instilled in them a love of English and poetry, and the need to be kind and generous to the underprivileged. Dick's younger brother, Dillon, is now a faculty member at Washington University in St. Louis where he teaches English and poetry. His younger brother, Chuck, is the director of a school program in Atlanta devoted to improving education in disadvantaged youth, and his younger brother, Warren, is a writer and associate editor for a newspaper in West Lebanon, New Hampshire.

Dick was born on August 23, 1935 in Atlanta, GA. In Figure $1 C$, we see a picture of Dick at age 2. While in high school at North Fulton High in Atlanta, Dick exhibited leadership qualities. He was captain of the football team (Fig. 1D) and president of the student body in his senior year (Table 1). After high school, Dick attended Vanderbilt University from 1953 to 1957 . During his freshman year of college, Dick wished to pursue a career in football. He was forced to give up football after tearing his anterior cruciate ligament while on the freshman football team. While at Vanderbilt, he majored in philosophy. Upon graduation, he was voted "Bachelor of Ugliness," which is Vanderbilt's term of endearment for the outstanding male graduate. Dick then attended Vanderbilt University School of Medicine where he received his M.D. in 1961.

Received May 19, 2008; accepted May 19, 2008.

Correspondence: Laurence A. Boxer, M.D., University of Michigan, Women's Hospital, Department of Pediatrics, 1500 East Medical Center Drive, Rm L2112, Ann Arbor, MI 48109; e-mail: laboxer@med.umich.edu

Presented at the 2008 Annual Meeting of the Pediatric Academic Societies, Honolulu, Hawaii.
Dick chose medicine as a career because he was profoundly influenced by his father and by his maternal grandfather who Dick deeply admired. His father had been responsible for instructing members of the Medical Corps in basic human biology in battlefield care during the Second World War. His grandfather's opinion as a venerable and wise judge indicated that a medical career led to a better opportunity than any other profession to help people.

During undergraduate and medical school, Dick served as an associate director of a YMCA Day Camp where he taught swimming to children. It was during this period of time that he developed a love of teaching, working with children, and assisting young people to improve their own lives. While in medical school, he met his wife, Mary Anne, and they were married before his senior year. Mary Anne taught kindergarten and later received a Ph.D. in Foundations of Education from the University of Colorado in 1979.

Upon completing medical school, Dick finished $2 \mathrm{y}$ of pediatric residency at Vanderbilt and then completed a senior residency in pediatrics in 1964 at the Children's Hospital in Boston. In Figure $1 E$, Dick is featured as a senior resident on the Pediatric Oncology floor at Children's Hospital.

For 2 y, 1964-1966, Dick practiced general pediatrics at the U.S. Army Hospital, Bad Canstatt, Germany. While in the Army, Dick recognized that he loved teaching and being part of an environment to pursue new scientific knowledge. Not surprisingly, he returned to Vanderbilt to prepare for a career in academic pediatrics. For a year beginning in 1966, he worked in the laboratory of Victor Najjar where he pursued isolating and characterizing the properties of an antimicrobial peptide derived from leukocytes. He then returned to Boston's Children's Hospital where he was appointed a fellow in Immunology in the laboratory of Fred Rosen from 1967 to 1970. During his fellowship, he began to carry out his important studies in host defense.

During these formative years, his son, Richard III, was born in 1962 while Dick was in medical school. Claiborne was born in 1964 during Dick's sojourn in the military, and in 1969, Kristin was born during his fellowship. Currently, Richard III is an orthopedist sport's medicine specialist practicing in Atlanta. His son Claiborne is a professor of neurology at UCSF and Kristin Rusk is a Ph.D. child psychologist in 

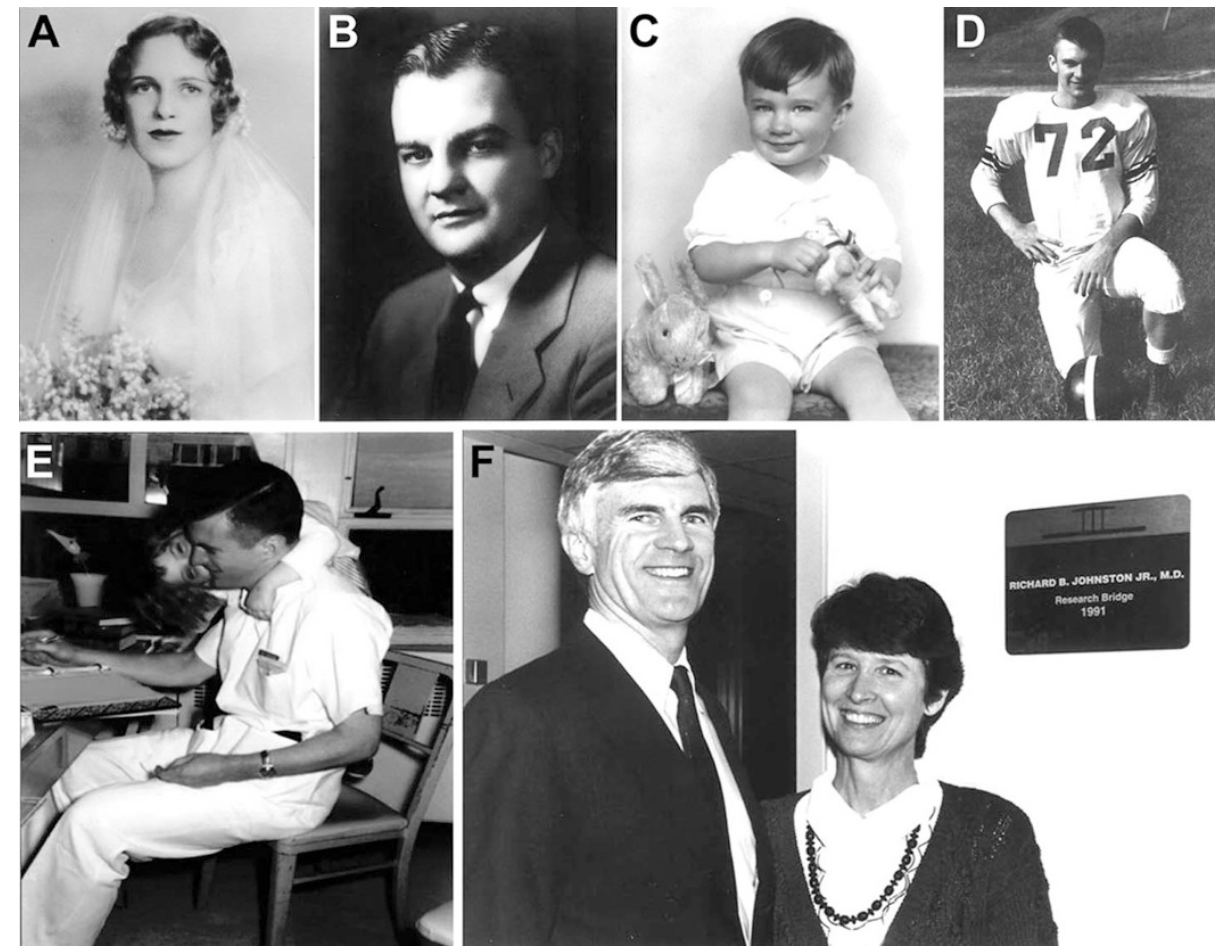

Figure 1. Wedding picture of $A$, Miss Jane Dillon to $B$, Mr. Richard Johnston Sr. $C$, Richard Johnston Jr, age 2. $D$, Richard Johnston Jr, captain of North Fulton High School football team. E, Richard Johnston, senior resident in pediatrics rotating on the pediatric oncology floor at Children's Hospital, Boston. $F$, Richard and Mary Ann Johnston on the bridge connecting the Children's Hospital of Philadelphia to the research laboratories of the University of Pennsylvania.

Boulder, CO. As you can see, all three children were influenced profoundly by Dick and entered health-related fields.

At $35 \mathrm{y}$ of age, Dick obtained his first job as an assistant professor of pediatrics and microbiology at the University of

Table 1. Leadership accomplishments as a youth

Junior class treasurer

President of student body—senior

Captain of football team

Bachelor of ugliness (Outstanding male graduate at Vanderbilt)

Table 2. Faculty positions

1970-1977

$1976-1977$

1977-1986

$1980-1986$

$1986-1992$

1992-1998

1992-1999

1999-present

2001-present

2004-2007

2007-2008
Assistant, Associate Professors of Pediatrics and Microbiology, University of Alabama

Visiting Associate Professor, Rockefeller University in the laboratory of Zanvil Cohn

Chairman of Pediatrics at NJC for Immunology and Respiratory Medicine and Professor, Pediatrics, University of Colorado

Vice-Chair, Department of Pediatrics, University of Colorado

Chair, Department of Pediatrics, University of Pennsylvania and Physician-in-Chief at CHOP, and William H. Bennett Professor of Pediatrics

Medical Director, March of Dimes Birth Defects Foundation

Adjunct Professor and Chief of Immunology at Yale

Professor, Pediatrics, University of Colorado

Associate Dean for Research Development, University of Colorado

Executive Vice President for Academic Affairs, National Jewish Medical and Research Center Vice President for Research Affairs National Jewish Medical and Research Center
Alabama-Birmingham where he rose to the position of associate professor (Table 2). After 6 y at Alabama, Dick moved to the Rockefeller University to expand his research in the study of macrophages under the guidance of Dr. Zanvil Cohn, one of the founding fathers of contemporary macrophage biology.

In 1977, he became Chairman of Pediatrics at the National Jewish Center for Immunology and Respiratory Medicine and Professor of Pediatrics at the University of Colorado. Dr. Johnston consequently served as Chairman of Pediatrics at Children's Hospital at Philadelphia/Penn. He then became Medical Director of the March of Dimes and simultaneously conducted National Institutes of Health funded research while serving as Chief of Pediatric Immunology at Yale. At Penn, he obtained financing to develop a bridge between Children's Hospital at Philadelphia and the University of Pennsylvania Research Building, which reflects Dick's commitment to the importance of research impacting on clinical care. In Figure $1 F$, the bridge that Dick help build was dedicated in 1991 to honor him.

In 1999, Dick returned to the University of Colorado and has held the position of Associate Dean for Research Development and Executive Vice President for Academic Affairs at the National Jewish Medical and Research Center.

Dick's contributions during his professional career have been numerable. While Chief of Pediatrics at the National Jewish Medical and Research Center from 1977 to 1986, Dick built the department from five to 30 members. He integrated the National Jewish Medical Research Center of Pediatrics with the Department of Pediatrics at the University of Colorado. Dick also served as President of the Society for Pediatric Research and the American Pediatric Society (APS). During 
his presidency of the Society for Pediatric Research in 19801981, Dick and his colleagues transformed the structure of the journal, Pediatric Research, such that a new editor was chosen every $5 \mathrm{y}$. While he was Medical Director of the March of Dimes from 1992 to 1999, he was instrumental in persuading the FDA to recommend fortifying grain products with folic acid to reduce birth defects. He also established a major grant program into the causes of preterm labor.

From 1996 through 1997, Dick served as President of APS. Currently, we are benefiting from the changes he made then. For instance, he changed the Annual Dinner for the Howland Awardee from a closed affair to an open dinner for all APS membership. He began the tradition of having the winner(s) of the March of Dimes prize in developmental biology give talk(s) at the PAS meeting.

His many accomplishments have been recognized by numerous awards and honors. He has been a member of advisory committees for various National Institutes of Health institutes, the Robert Wood Johnson Foundation, the CDC, FDA, Howard Hughes Medical Institute, the March of Dimes, the Pediatric Science Development Program, the Selection Committee for the Meade Johnson Award, and the Committee to establish the Sub-Board of Pediatric Infectious Disease. He has been elected to membership in the American Society of
Clinical Investigation and the Association of American Physicians. He received from the FDA, the Commissioner's Special Citation and H. W. Wiley Medal for Exceptional Contributions to the FDA. Dick was elected a member of the Institute of Medicine where he chaired several committees largely dealing with vaccine safety. He has served as Chairman of a Gordon Research Conference on Phagocytes. He was elected a Fellow of the American Association of the Advancement of Science.

Dr. Johnston has over 274 publications based on his research interests in host defense, the cell biology of phagocytes, and immunodeficiencies in childhood. His research includes the role of complement deficiency leading to susceptibility to pneumococcal infection in sickle cell disease; the first evidence of hydroxyl radical generation in a mammalian system; the first demonstration that phagocytes can release toxic oxidants at inflammatory sites; and the nature of complement and phagocyte deficiencies in immunodeficient patients.

Now Dr. Richard B. Johnston joins an illustrious group of Vanderbilt faculty and alumni, who have received this singular honor of the APS. These include Amos Christie and Millie Stahlman. Dick, with much aloha, we welcome you to the podium to receive the respect, gratitude, and affection of your colleagues. 